\title{
Comparative study of the efficacy of oral and intravenous maternal hydration in the management of third trimester oligohydramnios and it's effect on maternal and foetal outcome
}

\author{
Santosh Khajotia, Deepak Naraniya*, Shubha Meena
}

\begin{abstract}
Department of Obstetrics and Gynecology, S. P. Medical College, Bikaner, Rajasthan University of Health Sciences, Jaipur, Rajasthan, India
\end{abstract}

Received: 29 February 2020

Accepted: 30 March 2020

\author{
*Correspondence: \\ Dr. Deepak Naraniya, \\ E-mail: deepaknrn46@gmail.com
}

Copyright: (c) the author(s), publisher and licensee Medip Academy. This is an open-access article distributed under the terms of the Creative Commons Attribution Non-Commercial License, which permits unrestricted non-commercial use, distribution, and reproduction in any medium, provided the original work is properly cited.

\begin{abstract}
Background: Amniotic fluid is derived from maternal plasma in very early pregnancy by the 10th week of pregnancy. It forms an aquatic pond inside the amniotic cavity surrounding the fetus. It helps in fetal development. Aim of this study was to determine the impact of hydration therapy in patients complicated by oligohydramnios.

Methods: This was a prospective randomized clinical trial conducted on 200 women.

Results: Mean AFI in Group I was $4.47 \pm 0.90 \mathrm{~cm}$ before hydration therapy and $7.16 \pm 1.57 \mathrm{~cm}$ after hydration therapy with elevation by $60.18 \%$, similarly mean AFI in Group II was $4.52 \pm 0.83 \mathrm{~cm}$ before hydration therapy and $7.48 \pm 1.56$ $\mathrm{cm}$ after hydration therapy with elevation by $65.48 \%$. However, on comparing the two groups elevations in mean AFI was found statistically insignificant $(\mathrm{p}>0.05)$.

Conclusions: Oral hydration is non-invasive, low costing, does not exhaust the resource, convenient to the women with minimum side effects and can be done at home.
\end{abstract}

Keywords: Amniotic fluid, Hydration therapy, Non-invasive

\section{INTRODUCTION}

Amniotic fluid is derived from maternal plasma in very early pregnancy by the 10th week of pregnancy. It forms an aquatic pond inside the amniotic cavity surrounding the fetus. It helps in fetal development. ${ }^{1}$ It is mainly a transudate of fetal serum via the skin and umbilical cord. The mechanism of amniotic fluid production, consumption, composition and volume depends on the gestational age. Amniotic fluid volume at any time is a balance between production and consumption. Amniotic fluid has a number of important functions like development of musculoskeletal system, gastrointestinal tract development, lung development, provides essential nutrients to fetus, facilitating growth, movements, protects fetus from trauma by cushioning the fetus against mechanical and biological injury, and maintains body temperature and it has bacteriostatic properties. ${ }^{2}$ It helps to avert compression of umbilical cord and creates a physical space for the fetal skeleton to shape normally. From 16 weeks of gestation, the fetal skin becomes impermeable to water so amniotic fluid is formed increasingly from the fetal urine and lung fluid.

Normal amniotic fluid volume (AFV) changes with gestational age and ways of accurate estimation. Too little amniotic fluid represents oligohydramnios. Moreover, oligohydramnios has been defined as follows: $\mathrm{AFV}$ is less than $500 \mathrm{ml}$ at 32-36 weeks of gestation or maximum vertical pocket is less than $2 \mathrm{~cm}$ from late midtrimester or amniotic fluid index (AFI) is less than $5 \mathrm{~cm}$ or less than the 5 th percentile, from late mid-trimester. ${ }^{3}$ 
Excretion of urine by the fetus is the major source of amniotic fluid production in the second half of the pregnancy. Moreover, fluid secreted by the fetal respiratory tract contributes to amniotic fluid. Fetal swallowing is the major pathway of amniotic fluid clearance in the last half of gestation. Fetal skin is highly permeable in the first half of pregnancy but becomes keratinized at 22-25 weeks of gestation, significantly reducing transfer. The mother's fluid balance (and also therefore, the fetus) has a major effect on the AFV. Increased maternal fluid intake has been shown to increase the AFV in women with oligohydramnios. ${ }^{4}$

\section{METHODS}

This was a prospective randomized clinical trial conducted on 200 singleton pregnant females with gestation age $>28$ weeks with AFI $<5 \mathrm{~cm}$ during the period from $1^{\text {st }}$ December 2018 to $30^{\text {th }}$ November 2019 were taken for trial. All patients were submitted for elaborate clinical and obstetrical examination along with detailed history taking to satisfy the inclusion and exclusion criteria. AFI was assessed sonographically. After obtaining a written informed consent, patients were selected in two groups.

\section{Intravenous hydration group}

Those who received 2 liters of fluid (1 liter of Ringer lactate and 1 liter of 5\% GDW) intravenous given daily for 5 days and the response reassessed with ultrasonogram after the treatment on $5^{\text {th }}$ day.

\section{Oral hydration group}

Those who received 2 liters of water orally given daily for 5 days (other than routine hydration) and the response reassessed with ultrasonogram after the treatment on $5^{\text {th }}$ day.

\section{Statistical analysis}

To collect required information from eligible patients a pre-structured pre-tested proforma was used. For data analysis Microsoft excel and statistical software (SPSS version 17.0) was used and data were analyzed with the help of frequencies, figures, measures of central tendency, student's ' $t$ ' test, appropriate statistical test.

\section{RESULTS}

In Group I, out of total 100 cases $73 \%$ cases were while remaining $27 \%$ cases were unbooked. In group II out of total 100 cases, $68 \%$ and $32 \%$ cases of were booked and unbooked respectively $(\mathrm{p}>0.05)$ (Table 1$)$.

According to gestational age, majority of cases had their gestational age between 32-36 weeks where total 164 cases were found. $82 \%$ cases each belonged to Group I and II, while $15 \%$ and $3 \%$ cases of Group I had their gestational age $<32$ and $>36$ weeks and in Group II, $14 \%$ and $4 \%$ cases had their gestational age <32 and >36 weeks respectively and this difference was also found statistically insignificant ( $p>0.05$ ) (Table 2).

Table 1: Distribution of cases according to the booking status.

\begin{tabular}{|lll|ll|}
\hline $\begin{array}{l}\text { Booking } \\
\text { status }\end{array}$ & $\begin{array}{l}\text { Group I (IV } \\
\text { therapy) }\end{array}$ & \multicolumn{2}{l|}{$\begin{array}{l}\text { Group II (oral } \\
\text { therapy) }\end{array}$} \\
\hline Bo. & $\%$ & No. & \% \\
\hline Unbooked & 73 & $73.0 \%$ & 68 & $68.0 \%$ \\
\hline Total & 27 & $27.0 \%$ & 32 & $32.0 \%$ \\
\hline$\chi^{2}$ & 0.601 & & 100 & \\
\hline$p$ & 0.438 & & & \\
\hline
\end{tabular}

Table 2: Distribution of cases according to the gestational age.

\begin{tabular}{|lllll|}
\hline $\begin{array}{l}\text { Gestational } \\
\text { age (weeks) }\end{array}$ & \multicolumn{2}{l}{$\begin{array}{l}\text { Group I } \\
\text { (IV therapy) }\end{array}$} & \multicolumn{2}{l|}{$\begin{array}{l}\text { Group II } \\
\text { (oral therapy) }\end{array}$} \\
\cline { 2 - 5 } & No. & $\%$ & No. & \% \\
\hline$<32$ & 15 & $15 \%$ & 14 & $14 \%$ \\
\hline $32-36$ & 82 & $82 \%$ & 82 & $82 \%$ \\
\hline$>36$ & 3 & $3 \%$ & 4 & $4 \%$ \\
\hline Total & 100 & & 100 & \\
\hline Mean & 33.38 & & 33.73 & \\
\hline SD & 2.00 & & 1.96 & \\
\hline $\mathrm{t}$ & 1.248 & & & \\
\hline $\mathrm{p}$ & 0.214 & & & \\
\hline
\end{tabular}

Table 3: Distribution of cases on the basis of the AFI before hydration therapy.

\begin{tabular}{|c|c|c|c|c|}
\hline \multirow{2}{*}{$\begin{array}{l}\text { AFI } \\
(\mathbf{c m})\end{array}$} & \multicolumn{2}{|c|}{$\begin{array}{l}\text { Group I } \\
\text { (IV therapy) }\end{array}$} & \multicolumn{2}{|c|}{$\begin{array}{l}\text { Group II } \\
\text { (Oral therapy) }\end{array}$} \\
\hline & No. & $\%$ & No. & $\%$ \\
\hline$<3$ & 7 & $7.0 \%$ & 5 & $5.0 \%$ \\
\hline $3-5$ & 93 & $93.0 \%$ & 95 & $95.0 \%$ \\
\hline$>5$ & 0 & - & 0 & - \\
\hline Total & 100 & & 100 & \\
\hline Mean & 4.47 & & 4.52 & \\
\hline SD & 0.90 & & 0.83 & \\
\hline $\mathrm{t}$ & 0.406 & & & \\
\hline $\mathrm{p}$ & 0.685 & & & \\
\hline
\end{tabular}

In Group I, 93\% of cases had their AFI between 3-5 cm while in Group II, 95\% of cases had their AFI between 3$5 \mathrm{~cm}$ and no case in both groups had their AFI $>5 \mathrm{cms}$. Mean AFI in Group I was $4.47 \pm 0.90 \mathrm{~cm}$ and in Group II was $4.52 \pm 0.83 \mathrm{~cm}(\mathrm{p}>0.05)$ (Table 3). In Group I, $81 \%$ of cases had their AFI $>5 \mathrm{~cm}$ while $19 \%$ cases had their AFI between 3-5 cm while in Group II, $86 \%$ of cases had their AFI $>5$ and $12 \%$ of cases had their AFI between 3-5 $\mathrm{cm}$ while only $2 \%$ cases had their AFI $<3 \mathrm{~cm}$. Mean AFI in Group I was $7.16 \pm 1.57 \mathrm{~cm}$ and in Group II was $7.48 \pm 1.56 \mathrm{~cm}(\mathrm{p}>0.05)$ (Table 4). 
Table 4: Comparison between Group I and Group II on the basis of the AFI after hydration therapy.

\begin{tabular}{|c|c|c|c|c|}
\hline \multirow{2}{*}{$\begin{array}{l}\text { AFI } \\
(\mathrm{cm})\end{array}$} & \multicolumn{2}{|c|}{$\begin{array}{l}\text { Group I } \\
\text { (IV therapy) }\end{array}$} & \multicolumn{2}{|c|}{$\begin{array}{l}\text { Group II } \\
\text { (Oral therapy) }\end{array}$} \\
\hline & No. & $\%$ & No. & $\%$ \\
\hline$<3$ & 0 & - & 2 & $2.0 \%$ \\
\hline $3-5$ & 19 & $19.0 \%$ & 12 & $12.0 \%$ \\
\hline$>5$ & 81 & $81.0 \%$ & 86 & $86.0 \%$ \\
\hline Total & 100 & & 100 & \\
\hline Mean & 7.16 & & 7.48 & \\
\hline SD & 1.57 & & 1.56 & \\
\hline $\mathrm{t}$ & 1.444 & & & \\
\hline $\mathrm{p}$ & 0.150 & & & \\
\hline
\end{tabular}

\section{DISCUSSION}

In this study, majority of cases $(n=141)$ were booked and out of them 73 and 68 cases belonged to the IV hydration group and oral hydration group respectively while remaining 27 and 32 cases of IV hydration group and oral hydration group were unbooked and this difference was found statistically insignificant $(p>0.05)$ and not comparable with the studies already done (Table 1).

In this study, majority of cases had their gestational age between 32-36 weeks where total 164 cases were found and out of them 82 each belonged to IV hydration group and oral hydration group. In IV hydration group 15 and 3 cases had their gestational age $<32$ and >36 weeks respectively and in oral hydration group 14 and 4 cases had their gestational age $<32$ and $>36$ weeks respectively. This difference was found statistically insignificant ( $\mathrm{p}$ $>0.05$ ) (Table 2).

In this study, the mean gestational age in IV hydration group was $33.38 \pm 2.00$ week which is comparable with the study done by Cicily et al where the mean gestational age in IV hydration group was 35 weeks 2 days $\pm 7.9 . .^{5}$ In this study, the mean gestational age in oral hydration group was $33.73 \pm 1.96$ week which is comparable with the study done by Ghafarnejad et al where the mean gestational age in oral hydration group was 35.1 weeks. $^{6}$

In this study, AFI of all cases of IV hydration group and oral hydration group was $<5 \mathrm{~cm}$ before hydration therapy. After hydration therapy, 81 cases in IV hydration group and 86 cases in oral hydration group improved their AFI $>5 \mathrm{~cm}$ (Table 3 ).

In this study, the mean AFI before hydration therapy in IV hydration group and oral hydration group was $4.47 \pm 0.90$ and $4.52 \pm 0.83 \mathrm{~cm}$ respectively and after hydration therapy mean AFI was 7.16 \pm 1.57 and $7.48 \pm 1.56 \mathrm{~cm}$ respectively. This difference was found statistically insignificant and comparable with the studies done by Lorzadeh et al in their study, mean AFI before hydration therapy in IV hydration group and oral hydration group was $4.20 \pm 0.83$ and $3.6 \pm 1.0 \mathrm{~cm}$ respectively and mean AFI after hydration therapy was $5.98 \pm 0.94$ and $6.0 \pm 1.99 \mathrm{~cm}$ respectively. ${ }^{7}$ Study done by Nada et al also comparable with this study where AFI before hydration therapy in IV hydration group and oral hydration group was $5.1 \pm 0.4$ and $5.3 \pm 0.4 \mathrm{~cm}$ respectively and after therapy mean AFI was 7.74 \pm 0.96 and $8.28 \pm 0.8$ cm respectively (Table 4). ${ }^{8}$

Study done by Patil et al also comparable with this study. ${ }^{9}$ In their study, the mean AFI before hydration therapy in IV hydration group and oral hydration group was $4.98 \pm 1.86$ and $4.91 \pm 1.58 \mathrm{~cm}$ respectively and mean AFI after therapy was $6.18 \pm 2.2$ and $6.49 \pm 2.22 \mathrm{~cm}$ respectively.

\section{CONCLUSION}

Though further studies are mandatory to reach sound conclusions, available data suggests that maternal hydration may be a safe, well tolerated and useful strategy to improve amniotic fluid volume in cases of oligohydramnios. The result of the current study shows that both oral and intravenous hydration significantly increased the amniotic fluid index in the isolated or idiopathic oligohydramnios. Neither oral nor intravenous hydration appeared advantageous over the other so either method can be used.

However, oral hydration is non-invasive, low costing, does not exhaust the resource, convenient to the women with minimum side effects and can be done at home.

Funding: No funding sources

Conflict of interest: None declared

Ethical approval: The study was approved by the Institutional Ethics Committee

\section{REFERENCES}

1. Cunningham FG, Leveno KJ, Bloom SL, Hauth JC, Gilstap LC, Wenstrom KD, et al. Growth and Development. In: Cunningham FG, Leveno KL, Bloom SL eds. Williams Obstetrics. $23^{\text {rd }}$ ed. New York, NY: McGraw-Hill; 2010:78-106.

2. Ross MG, Brace R. Amniotic fluid biology- basic and clinical aspects. J Maternal Fetal Med. 2001;10:2-19.

3. Morris RK, Meller CH, Tamblyn J, Malin GM, Riley RD, Kilby MD, et al. Association and prediction of amniotic fluid measurements for adverse pregnancy outcome: Systematic review and meta-analysis. BJOG. 2014;121:686-99.

4. Patient: Making Lives Better. Oligohydramnios, 2017. Available at: https://patient.info/doctor/oligohydramnios. Accessed on $24^{\text {th }}$ January 2020.

5. Cicily TJ, Sams S, Gopal AK Effect of hydration therapy on oligohydramnios. Int J Reprod Contracept Obstet Gynecol. 2017;6:1800-5. 
6. Ghafarnejad M, Tehrani MB, Anaraki FB, Mood NI, Nasehi L. Oral hydration therapy in oligohydramnios. J Obstet Gynecol Res. 2009;35(5):895-900.

7. Lorzadeh N, Kazemirad S, Lorzadeh M, Najafi S. Comparison of the effect of oral and intravenous fluid therapy on women with oligohydramnios. Res $\mathbf{J}$ Obstet Gynecol. 2008;1:25-9.

8. Nada Z. Oral and intravenous maternal hydration in third trimester idiopathic oligohydramnios: effects and duration. IOSR J Nurs Health Sci. 2015;4(5):225.
9. Patil N, Abhigna V. A randomized controlled trial to compare the efficacy of three different methods of maternal hydration for oligohydramnios. JKIMSU. 2018;7(1):47-54.

Cite this article as: Khajotia S, Naraniya D, Meena S. Comparative study of the efficacy of oral and intravenous maternal hydration in the management of third trimester oligohydramnios and it's effect on maternal and foetal outcome. Int J Reprod Contracept Obstet Gynecol 2020;9:2077-80. 